\title{
Primary combined adenoid cystic carcinoma, basaloid squamous cell carcinoma, and squamous cell carcinoma of the esophagus
}

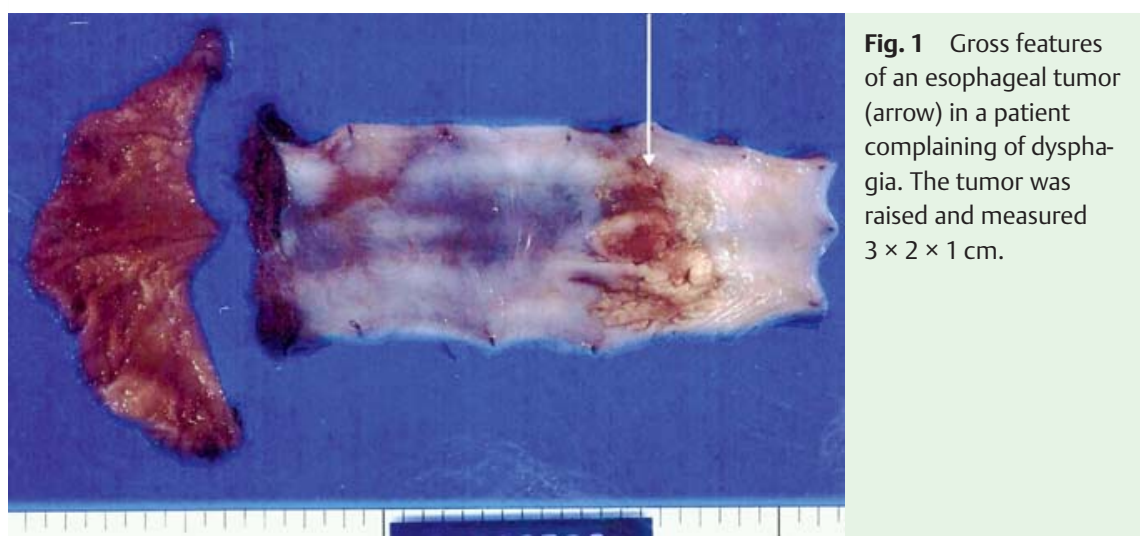

Reports of adenoid cystic carcinoma and basaloid squamous cell carcinoma of the esophagus are rare [1-4], while esophageal combined carcinoma is very rare [5]. Most cases of combined carcinoma of the esophagus consist of squamous cell carcinoma, adenocarcinoma, and small cell carcinoma [5]. This is the first report of combined adenoid cystic carcinoma, basaloid squamous cell carcinoma, and squamous cell carcinoma of the esophagus.

A 48-year-old man was admitted because of dysphagia. Endoscopy revealed a tumor in the esophagus and biopsy samples showed adenoid cystic carcinoma and squamous cell carcinoma. The esophagus was resected and the resected specimen contained a raised tumor measuring $3 \times 2$ $\times 1 \mathrm{~cm}(\bullet$ Fig. 1$)$.

Microscopically the tumor was composed of adenoid cystic carcinoma (proportion of tumor: 30\%; Fig. 2 a), basaloid squamous cell carcinoma (proportion of tumor: 40\%; Fig. 2b), and keratinizing squamous cell carcinoma (proportion of tumor: 30\%; Fig. 2c).

An immunohistochemical study using the Dako Envision method, as previously reported [6], was carried out ( $\bullet$ Table 1 ).
Positive findings characteristic of the adenoid cystic carcinoma component included presence of mucins, p63, CD10, KIT, platelet-derived growth factor- $\alpha$ (PDGFRA), CA19-9, and MUC1, those characteristic of the basaloid squamous cell carcinoma component included presence of p63, p53, PDGFRA ( Fig. 2 d), CEA, and CA19-9, and those characteristic of the squamous cell carcinoma component included presence of p63, p53, EMA, and MUC1.

Adenoid cystic carcinoma of esophagus is thought to arise from esophageal glands, basaloid squamous cell carcinoma from transdifferentiation of squamous cell carcinoma, and squamous cell carcinoma from the surface squamous epithelium. I believe that in the present case, the adenoid cystic carcinoma and basaloid squamous cell carcinoma components of the tumor were derived from the squamous cell carcinoma, as suggested by the immunohistochemical study. The squamous cell carcinoma component showed glandular differentiation and expression of MUC1, which is unusual, indicating the presence of the apomucin gene in this component of the tumor. The expression of PDGFRA and CA19-9 in the basaloid squamous cell carcinoma was also unusual, and it might have represented transformation of this component into adenoid cystic carcinoma. The adenoid cystic carcinoma component showed typical immunohistochemical features of this tumor.
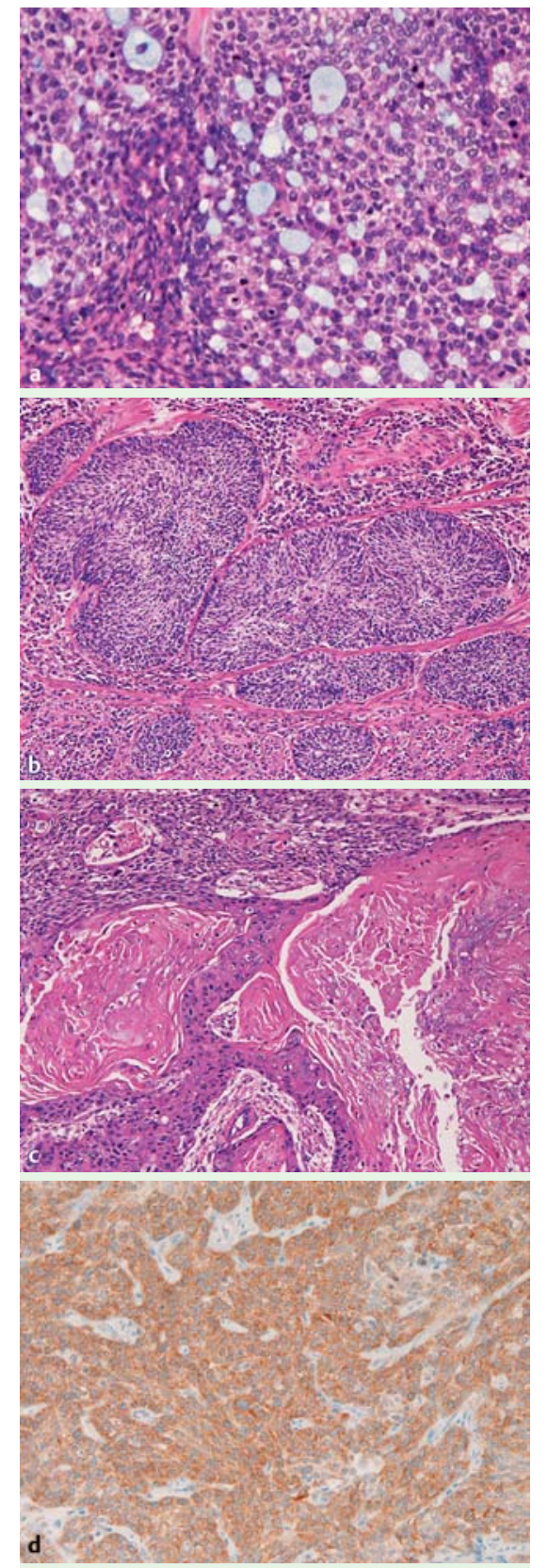

Fig. 2 a-c Microscopic findings (hematoxylin and eosin, magnification $\times 200$ ). a Adenoid cystic carcinoma component: note the characteristic cribriform pattern with expression of mucins. b Basaloid squamous cell carcinoma component: there is characteristic basaloid cell proliferation and peripheral palisading. c Squamous cell carcinoma component: typical features of keratinizing squamous cell carcinoma are seen. $\mathbf{d}$ Immunohistochemical findings: platelet-derived growth factor- $\alpha$ expressed in basaloid squamous cell carcinoma component. 
Table 1 Immunohistochemical findings in a patient with combined esophageal carcinoma.

\begin{tabular}{|c|c|c|c|}
\hline & \multicolumn{3}{|c|}{ Combined carcinoma components } \\
\hline & $\begin{array}{l}\text { Adenoid cystic } \\
\text { carcinoma }\end{array}$ & $\begin{array}{l}\text { Basaloid squamous } \\
\text { cell carcinoma }\end{array}$ & $\begin{array}{l}\text { Squamous cell } \\
\text { carcinoma }\end{array}$ \\
\hline d-PA & + & - & - \\
\hline Alcian blue & + & - & - \\
\hline CKAE1 & ++ & +++ & +++ \\
\hline CKCAM5.2 & + & + & - \\
\hline CK34BE12 & + & ++ & ++ \\
\hline CK5/6 & + & ++ & ++ \\
\hline CK7 & + & + & - \\
\hline CK8 & - & - & - \\
\hline CK14 & + & + & +++ \\
\hline CK18 & + & + & + \\
\hline CK19 & + & ++ & + \\
\hline CK20 & - & - & - \\
\hline p63 & +++ & +++ & ++ \\
\hline Vimentin & + & - & - \\
\hline CD34 & - & - & - \\
\hline Ki67 & $30 \%$ & $50 \%$ & $40 \%$ \\
\hline p53 & + & +++ & ++ \\
\hline CD10 & + & - & - \\
\hline Synaptophysin & - & - & - \\
\hline KIT & ++ & - & - \\
\hline PDGFRA & ++ & ++ & - \\
\hline CEA & - & + & - \\
\hline EMA & - & - & + \\
\hline Desmin & - & - & - \\
\hline S100 & - & - & - \\
\hline ASMA & - & - & - \\
\hline CA19-9 & + & + & - \\
\hline Chromogranin & - & - & - \\
\hline MUC 1 & + & - & + \\
\hline MUC2 & - & - & - \\
\hline MUC5AC & - & - & - \\
\hline MUC6 & - & - & - \\
\hline
\end{tabular}

CK, cytokeratin; PDGFRA, platelet-derived growth factor; CEA, carcinoembryonic antigen; EMA, epithelial membrane antigen; ASAM, smooth muscle actin; CA19-9, carcinoma antigen 19-9.
Endoscopy_UCTN_Code_CCL_1AB_2AC_3AB

\section{Competing interests: None}

\section{T. Terada}

Department of Pathology, Shizuoka City

Shimizu Hospital, Shizuoka, Japan

\section{References}

1 Morisaki Y, Yoshimizu Y, Hiroyasu $U$ et al. Adenoid cystic carcinoma of the esophagus: report of a case and review of the Japanese literature. Surg Today 1996; 26: 1006-1009

2 Kabuto T, Taniguchi K, Iwanaga $T$ et al. Primary adenoid cystic carcinoma of the esophagus. Cancer 1979; 43: 2452-2456

3 Sarbia $M$, Verreet $P$, Bittinger $F$ et al. Basaloid squamous cell carcinoma of the esophagus: diagnosis and prognosis. Cancer 1997; 79: $1871-1878$

4 Nishimura W, Naomoto $Y$, Hamaya $K$ et al. Basaloid squamous cell carcinoma of the esophagus: diagnosis based on immunohistochemical analysis. J Gastroenterol Hepatol 2001; 16: 586-590

5 Yamamoto J, Ohshima K, Ikeda S et al. Primary esophageal small cell carcinoma with concomitant invasive squamous cell carcinoma or carcinoma in situ. Hum Pathol 2003; 34: 1108-1115

6 Terada T, Kawaguchi M, Furukawa $\mathrm{K}$ et al. Minute mixed ductal-endocrine carcinoma of the pancreas with predominant intraductal growth. Pathol Int 2002; 52: 740 - 746

\section{Bibliography}

DOI $10.1055 / \mathrm{s}-0030-1256784$

Endoscopy 2012; 44: E102 -E103

(c) Georg Thieme Verlag KG Stuttgart · New York . ISSN 0013-726X

\section{Corresponding author \\ T. Terada}

Department of Pathology

Shizuoka City Shimizu Hospital

Miyakami 1231 Shimizu-Ku

Shizuoka 424-8636

Japan

Fax: 81-54-3361315

piyo0111jp@yahoo.co.jp 